\title{
A study on the effects of potassium borohydride in pulp and paper production from black locust (Robinia pseudoacacia L.) wood
}

\author{
Mustafa Çiçekler ${ }^{a}{ }^{*}$ (iD), Saniye Erkana ${ }^{a}$, Ahmet Tutuş ${ }^{a}$ (iD
}

\begin{abstract}
In this study, the effects of potassium borohydride $\left(\mathrm{KBH}_{4}\right)$ added to the cooking liquor (white liquor) in pulp and paper production from black locust (Robinia pseudoacacia L.) woods on the chemical, physical and optical properties of the pulp were investigated. Soda $(\mathrm{NaOH})$ method, which is one of the environmentally friendly cooking methods, was used in the pulp production from $R$. pseudoacacia woods. By adding 0, 0.3, 0.5 and $0.7 \% \mathrm{KBH}_{4}$ to the white liquor, four different cooking experiments were carried out. The yields, kappa numbers and viscosity values of the pulps were measured with the relevant standards. Test papers were produced from each pulp and their physical and optical properties were determined. With $0.7 \% \mathrm{KBH}_{4}$ added to the cooking solution, the total yield and viscosity increased by $9.54 \%$ and $10.4 \%$, respectively compared to $\mathrm{KBH}_{4}$-free pulp, while the kappa number decreased by $9.48 \%$. As a result of statistical analysis, it has been observed that there is no significant difference between the physical and optical properties of the papers produced from $\mathrm{KBH}_{4}$-free and $\mathrm{KBH}_{4}$-added pulps. Consequently, it was concluded that adding $\mathrm{KBH}_{4}$ to the white liquor in the pulp production from $R$. pseudoacacia wood with soda method, positively affected the chemical properties of the pulps and did not have a significant effect on the physical and optical properties.

Keywords: Black locust, Potassium borohydride, Pulp, Soda method
\end{abstract}

\section{Yalancı akasya (Robinia pseudoacacia L.) odunundan kağıt hamuru ve kağıt üretiminde potasyum borhidrürün etkileri üzerine bir çalışma}

\begin{abstract}
Özet: Bu çalışmada, yalancı akasya (Robinia pseudoacacia L.) odunlarından kağıt hamuru ve kağıt üretiminde pişirme çözeltisine (beyaz çözelti) eklenen potasyum borhidrürün $\left(\mathrm{KBH}_{4}\right)$ kağıt hamurunun kimyasal, fiziksel ve optik özellikleri üzerindeki etkileri araştırılmıştır. R. pseudoacacia odunlarından kağıt hamuru üretiminde çevre dostu pişirme yöntemlerinden biri olan Soda $(\mathrm{NaOH})$ yöntemi kullanılmıştır. Beyaz çözeltiye \%0, 0.3, 0.5 ve $0.7 \mathrm{KBH}_{4}$ ilave edilerek dört farklı pişirme deneyi gerçekleştirilmiştir. Kağıt hamurlarının verimleri, kappa sayıları ve viskozite değerleri ilgili standartlara bağlı kalınarak ölçülmüştür. Her bir deneyden elde edilen kağıt hamurlarından test kağıtları üretilerek fiziksel ve optik özellikleri belirlenmiştir. Beyaz çözeltiye eklenen $\% 0.7 \mathrm{KBH}_{4}$ ile toplam verim ve viskozite, $\mathrm{KBH}_{4}$ içermeyen kağıt hamurlarına göre sırasıyla \%9.54 ve \%10.4 artarken, kappa sayısı \%9,48 azalmıştır. İstatistiksel analizler sonucunda $\mathrm{KBH}_{4}$ içermeyen ve $\mathrm{KBH}_{4}$ katkılı kağıt hamurlarından üretilen kağıtların fiziksel ve optik özellikleri arasında önemli bir fark olmadığı görülmüştür. Sonuç olarak, yalancı akasya odunlarından soda yöntemi ile kağıt hamuru üretiminde pişirme çözeltisine $\mathrm{KBH}_{4}$ ilave edilmesinin kimyasal özellikleri olumlu yönde etkilediği, fiziksel ve optik özellikler üzerinde belirgin bir etki göstermediği sonucuna varılmıştır.

Anahtar kelimeler: Yalancı akasya, Potasyum borhidrür, Kağıt hamuru, Soda yöntemi
\end{abstract}

\section{Introduction}

Mechanical, semi-chemical, chemical and biological methods are used to produce pulp and paper. Chemical pulping is one of the most preferred methods in the world. It can be classified as sulphate (Kraft), soda and sulphite methods (Smook, 1992). Kraft method is one of the most used methods in pulp production and kraft pulp is stronger and darker. In the soda pulping known as an environmentally friendly method, the strengths of the pulp are lower than that of kraft pulps, while the pulp color is lighter (Kirci, 2006). Chemical recovery in soda method is simpler than kraft method. As one of the main chemicals used in the kraft pulping, $\mathrm{Na}_{2} \mathrm{~S}$, mercaptans and $\mathrm{H}_{2} \mathrm{~S}$ gases are released into the atmosphere during cooking and recovery, unpleasant odors occur. In addition, it has an abrasive feature during cooking. Therefore, many factories established as environmentalists prefer to use the soda method (Tutus and Cicekler, 2016; Istek and Ozkan, 2008).

Less bleaching chemicals can be used to obtain high brightness value from the pulp obtained by soda method (Misra, 1973; Eroglu, 1981). However, compared to the kraft method, the paper quality and yield are lower, and the cooking time is longer to reach the same delignification rate (Eroglu, 1981). One of the main reasons for using soda method instead of sulfate and sulfite method in pulp production from annual plants and hardwood species is that the cooking time of softwood species is very long (6-7 hours) in soda method. Another reason is that the strength properties of the pulp produced from softwood using the soda method are quite low compared to the other two methods. The fiber lengths of hardwoods are short and

\footnotetext{
a Kahramanmaraş Sütçü İmam Üniversitesi, Orman Fakültesi, Orman Endüstri Müh. Bölümü, Onikișubat, Kahramanmaraş

(a)

Corresponding author (İletişim yazarı): mcicekler87@gmail.com

$\checkmark \quad$ Received (Geliş tarihi): 13.01.2021, Accepted (Kabul tarihi): 09.02.2021
}

Citation (Atıf): Çiçekler, M., Erkan, S., Tutuş, A., 2021. A study on the effects of potassium borohydride in pulp and paper production from black locust (Robinia pseudoacacia L.) wood. Turkish Journal of Forestry, 22(1): 33-37. DOI: $10.18182 /$ tjf.860207 
therefore their strength properties are lower than that of softwood fibers. However, papers with high opacity, better air permeability, soft and smooth surface are produced from the pulps obtained from hardwood (Smook, 1992).

With the recently developing technologies, progress has been made in terms of efficiency in soda cooking. The main reasons are minimizing the secondary peeling reaction by using low temperature and alkali ratio in cooking processes. However, it should be kept in mind that regardless of the methods used to increase the yield, it may adversely affect the strength properties of the pulp (Gulsoy et al., 2016; Cicekler and Tutus, 2019). When the temperature reaches $100{ }^{\circ} \mathrm{C}$ in alkali pulping, peeling reactions begin. The peeling reaction starts at the reducing end parts of the polysaccharide chain, separating the monomers one by one from the main chain. In this phase (primary peeling), decreases in polymerization degree and yield occur (Smook, 1992; Kirci, 2006; Brännvall, 2018). For this reason, various chemicals are used in cooking processes to increase yield and improve pulp properties. These chemicals are generally used to stop or slow down the peeling reactions that occur in cooking under alkaline conditions such as soda and kraft. Because, with the peeling reaction, shortening appears in the cellulose chains and negative effects arise on the pulp yield and physical properties (Tavast and Brännvall, 2017; Cicekler and Tutus, 2019; Birinci et al., 2020).

During cooking, aldehyde end groups are suitable for reduction, but are not very economical. For this purpose, additives such as boron compounds and anthraquinone (AQ) can be used. However, yield improvement processes also increase the chemical cost. Many attempts have been made to stop the peeling reaction and it is still the subject of many studies (Akgul and Temiz, 2006; Istek and Ozkan, 2008; Gulsoy and Eroglu, 2011; Tutus et al., 2011; Tutus et al., 2015; Tutus and Cicekler, 2016; Akgul et al., 2018). In these studies, it has been reported that AQ and boron compounds have a positive effect on the pulp properties.

As seen in Table 1, sodium borohydride $\left(\mathrm{NaBH}_{4}\right)$ is one of the most studied boron compounds in improving pulp properties, and the use of potassium borohydride $\left(\mathrm{KBH}_{4}\right)$ is very recent. During the cooking process, $\mathrm{KBH}_{4}$ prevents the peeling reaction that may occur by reducing the carbonyl group at the reducing ends of the cellulose chain to the hydroxyl group. This reaction is seen not only in cellulose but also in hemicelluloses. Therefore, the yield loss caused by the peeling reaction is prevented and the yield of the obtained pulp increases (Akgul and Temiz, 2006; Istek and Ozkan, 2008).

In this study, the effects of $\mathrm{KBH}_{4}$ added to the white liquor on the properties of the pulps produced with using soda method from $R$. pseudoacacia wood were investigated.

\section{Material and method}

\subsection{Material}

Black locust (R. pseudoacacia) wood samples used in pulp production were procured as logs from Osmaniye Forestry Management Directorate. According to relevant standards, $5 \mathrm{~cm}$ thick samples were taken from $15 \mathrm{~cm}$ above root, right in the middle of stem, and $15 \mathrm{~cm}$ below the crown. Chemicals used in cooking processes were purchased from Merck KGaA Inc. and Sigma-Aldrich Inc.

\subsection{Pulping and papermaking}

$R$. pseudoacacia wood samples were chipped into 25-35 mm length x 3-7 mm thickness and cleaned from dust and contaminants. In order to be used in cooking trials, $500 \mathrm{gr}$ oven dried chips were weighted and stored in polyethylene bags. Soda cooking method was used to obtain pulps from $R$. pseudoacacia chips and $\mathrm{KBH}_{4}$ were added to white liquor to improve pulp properties. The pulping conditions applied to the $R$. pseudoacacia chips were presented in Table 2.

The chips were filled by manually into an electrically heated digester and the pulp slurry was poured onto a screen (200 mesh) after cooking was completed. The obtained pulps were washed until black liquor was taken away. The black solution-free pulps were sieved through a screen with $0.15 \mathrm{~mm}$ slotted to remove non-fibrous and uncooked portions. The suitable (screened) and unsuitable (screen reject) pulps for papermaking were weighted and yields were calculated.

The pulps obtained from $R$. pseudoacacia chips were mixed homogeneously at a certain density in a 10-liter capacity mixer before the test paper formation and the freeness level was determined using the Schopper Riegler tool according to the ISO 5267-1 (1999) method. After the pulps were beaten at $35 \pm 5 \mathrm{SR}$ freeness level in a Hollander device, test papers with $70\left(\mathrm{~g} / \mathrm{m}^{2}\right)$ grammages were produced with Rapid-Kothen paper machine according to ISO 5269-2 (2014).

Table 1. Some studies investigating the effects of $\mathrm{NaBH}_{4}$ and $\mathrm{KBH}_{4}$ on pulp properties

\begin{tabular}{|c|c|c|}
\hline Raw material & Pulping method & Literature \\
\hline Betula pendula & Kraft-NaBH 4 & Pettersson and Rydholm, 1961 \\
\hline Pinus radiata & Kraft-NaBH 4 & Meller, 1963 \\
\hline Wheat straw & $\mathrm{Kraft}_{-} \mathrm{NaBH}_{4}$ & Tutus and Alma, 2005 \\
\hline Abies nordmanniana & Kraft-NaBH 4 & Akgul and Temiz, 2006 \\
\hline Populus tremula & Kraft-NaBH 4 & Istek and Ozkan, 2008 \\
\hline Pinus brutia & Kraft-NaBH 4 & Copur and Tozluoglu, 2008 \\
\hline Picea orientalis & Kraft-NaBH 4 & Tutus et al., 2010 \\
\hline Pinus nigra & Kraft-NaBH 4 & Gulsoy and Eroglu, 2011 \\
\hline Wheat straw & Soda-NaBH 4 & Tutus and Cicekler, 2016 \\
\hline Pinus brutia & Kraft-NaBH 4 & Tutus et al., 2012 \\
\hline Diospyros kaki & Kraft-NaBH 4 & Tutus et al., 2014 \\
\hline Prunus armeniaca & Kraft-NaBH 4 & Tutus et al., 2016 \\
\hline Pinus pinaster & $\mathrm{Kraft}_{-} \mathrm{KBH}_{4}$ & Gulsoy et al., 2016 \\
\hline Pinus brutia & Kraft- $\mathrm{KBH}_{4}$ & Cicekler and Tutus, 2019 \\
\hline Pinus pinea & Soda-KBH ${ }_{4}$ & Erkan et al., 2020 \\
\hline
\end{tabular}

Table 2. Pulping conditions applied to $R$. pseudoacacia chips

\begin{tabular}{lcc}
\hline Pulping Condition & Unit & Value \\
\hline Active alkali charge & $\%$ & 20 \\
$\mathrm{KBH}_{4}$ charge & $\%$ & $0,0.3,0.5,0.7$ \\
Liquor-to-raw material & $\mathrm{L} / \mathrm{kg}$ & $5 / 1$ \\
Cooking temperature & ${ }^{\circ} \mathrm{C}$ & 160 \\
Time to maximum temperature & $\mathrm{min}$ & 40 \\
Time at maximum temperature & $\mathrm{min}$ & 110 \\
\hline
\end{tabular}




\subsection{Determination of chemical, physical and optical properties}

The kappa numbers and viscosity values as chemical properties of the pulps were measured according to TAPPI T236 (2013) and ISO 5351 (2010) standards, respectively. Test papers were conditioned according to TAPPI T402 (2013) standard at $23 \pm 1{ }^{\circ} \mathrm{C}$ and $50 \pm 1 \%$ relative humidity for a day. The physical, optical tests and standards applied to the papers were given in Table 3.

The tests indicated in Table 3 were applied to ten papers produced from each pulp and the effects of $\mathrm{KBH}_{4}$ were examined using the averages of the data. Statistical analysis of the obtained data was performed with the SPSS statistical package. Data of chemical, physical and optical properties of the pulp were analyzed using a computerized statistical program to determine variance, and by applying the Duncan test at a $\mathrm{P} \leq 0.05$ confidence level.

\section{Results and discussion}

\subsection{Chemical properties of the pulps}

The pulp yields, kappa numbers and viscosity values were given in Table 4.

By adding $0.7 \% \mathrm{KBH}_{4}$ to the white liquor, the screened and total pulp yields increased compared to the $\mathrm{KBH}_{4}$-free pulp yields. Since boron compounds such as $\mathrm{NaBH}_{4}$ and $\mathrm{KBH}_{4}$ has the ability to stop or slow down the peeling reactions occurring in cellulose and hemicellulose chains, it increased the pulp yield (Istek and Gonteki, 2009; Cicekler and Tutus, 2019; Erkan et al., 2020). In Fig. 1, the screened yield increased as $\mathrm{KBH}_{4}$ charge added to the white liquor increased by $8.69 \%$.
Addition of $\mathrm{KBH}_{4}$ into white liquor decreased the kappa number of the pulps. Since $\mathrm{KBH}_{4}$ stops the peeling and increases the yield, the cellulose content of the pulp increases. The kappa number is generally used to estimate the lignin content in the pulp and to determine its bleachability (Correia et al., 2018). Considering the increase in the cellulose content decreased the lignin content compared to the whole pulp, the kappa numbers of the $\mathrm{KBH}_{4}$-added pulps were found to be lower (Fig. 1). Compared to $\mathrm{KBH}_{4}$-free pulps, the kappa number reduced by $5 \%$ with adding $0.7 \% \mathrm{KBH}_{4}$ to the cooking solution. Decreases in kappa numbers have been mentioned with the addition of boron compounds $\mathrm{KBH}_{4}$ and $\mathrm{NaBH}_{4}$ in pulping processes (Copur and Tozluoglu, 2008; Gulsoy and Eroglu, 2011; Istek and Gonteki, 2009; Cicekler and Tutus, 2019; Erkan et al., 2020). The viscosity of the pulp refers to the degree of polymerization (DP) of the cellulose. As mentioned earlier, the shortening of the cellulose chain naturally also stops, as $\mathrm{KBH}_{4}$ stops the peeling reaction. Therefore, the DP of $\mathrm{KBH}_{4}$-added pulps is higher than for that of $\mathrm{KBH}_{4}$-free pulps (Fig. 1). Viscosity values of $0.7 \%$ $\mathrm{KBH}_{4}$-added pulps were $10.4 \%$ higher than that of $\mathrm{KBH}_{4}^{-}$ free pulps.

Some physical and optical properties of the pulps obtained from $R$. pseudoacacia chips with soda- $\mathrm{KBH}_{4}$ method were given in Table 5 below.

Table 3. The physical and optical test and standards applied to the papers

\begin{tabular}{ll}
\hline Physical and optical tests & Standards \\
\hline Breaking length $(\mathrm{km})$ & TAPPI T494 (2006) \\
Burst index $\left(\mathrm{kPa} \mathrm{m}^{2} / \mathrm{g}\right)$ & TAPPI T403 $(2015)$ \\
ISO whiteness $(\%)$ & ISO $11476(2010)$ \\
ISO brightness (\%) & ISO 2469 $(2014)$ \\
Yellowness (E313) & ASTM E313 (2020) \\
\hline
\end{tabular}

Table 4. Some chemical properties of the R. pseudoacacia pulps.

\begin{tabular}{ccccccc}
\hline \multirow{2}{*}{ Cooking no } & $\begin{array}{c}\mathrm{KBH}_{4} \text { charge } \\
(\%)\end{array}$ & $\begin{array}{c}\text { Screened yield } \\
(\%)\end{array}$ & $\begin{array}{c}\text { Screen reject } \\
(\%)\end{array}$ & $\begin{array}{c}\text { Total yield } \\
(\%)\end{array}$ & $\begin{array}{c}\text { Kappa number } \\
\left(\mathrm{cm}^{3} / \mathrm{g}\right)\end{array}$ \\
\hline 1 & 0.0 & $40.46 \mathrm{c}$ & $0.42 \mathrm{~b}$ & $40.88 \mathrm{c}$ & $23.2 \mathrm{~b}$ & $559 \mathrm{c}$ \\
2 & 0.3 & $40.94 \mathrm{c}$ & $0.38 \mathrm{~b}$ & $41.02 \mathrm{c}$ & $25.6 \mathrm{c}$ & $790 \mathrm{c}$ \\
3 & 0.5 & $42.28 \mathrm{~b}$ & $0.29 \mathrm{a}$ & $43.28 \mathrm{~b}$ & $23.4 \mathrm{~b}$ & $60 \mathrm{c}$ \\
4 & 0.7 & $43.98 \mathrm{a}$ & $0.79 \mathrm{c}$ & $44.78 \mathrm{a}$ & $21.0 \mathrm{a}$ & $602 \mathrm{c}$ \\
\hline
\end{tabular}

*DP refers to degree of polymerization. Mean values with the same lower-case letters are not significantly different at $95 \%$ confidence level (p $>0.05$ ) according to Duncan's mean separation test.

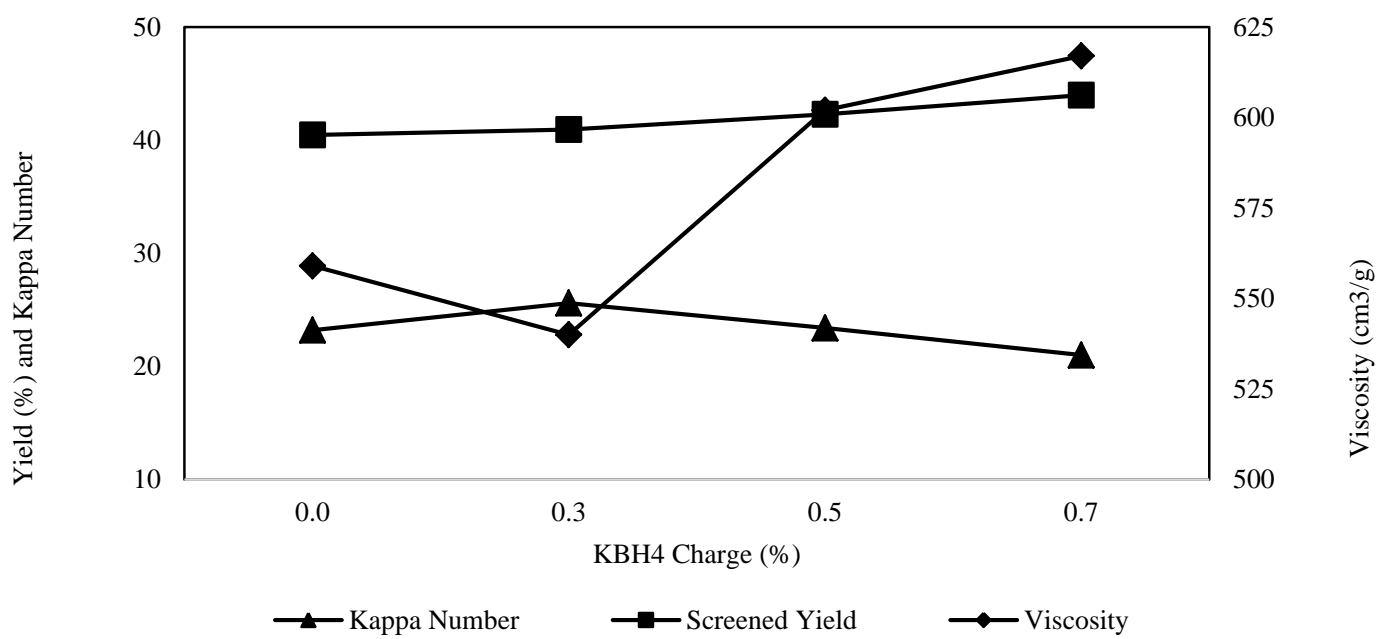

Figure 1. Effects of $\mathrm{KBH}_{4}$ on some chemical properties of $R$. pseudoacacia pulps 
Table 5. Some physical and optical properties of the $R$. pseudoacacia pulps.

\begin{tabular}{cccccc}
\hline Cooking no & $\begin{array}{c}\mathrm{KBH}_{4} \text { Charge } \\
(\%)\end{array}$ & $\begin{array}{c}\text { Breaking length } \\
(\mathrm{km})\end{array}$ & $\begin{array}{c}\text { Burst index } \\
\left(\mathrm{kPa} \cdot \mathrm{m}^{2} / \mathrm{g}\right)\end{array}$ & $\begin{array}{c}\text { Whiteness } \\
(\text { ISO } \%)\end{array}$ & $\begin{array}{c}\text { Brightness } \\
(\text { ISO } \%)\end{array}$ \\
\hline 1 & 0.0 & $5.49 \mathrm{a}$ & $2.87 \mathrm{a}$ & $22.73 \mathrm{a}$ & $16.50 \mathrm{a}$ \\
2 & 0.3 & $5.35 \mathrm{a}$ & $2.80 \mathrm{a}$ & $21.53 \mathrm{a}$ & $41.09 \mathrm{a}$ \\
3 & 0.5 & $5.43 \mathrm{a}$ & $2.84 \mathrm{a}$ & $22.02 \mathrm{a}$ & $40.27 \mathrm{a}$ \\
4 & 0.7 & $5.47 \mathrm{a}$ & $2.66 \mathrm{a}$ & $23.11 \mathrm{a}$ & $16.12 \mathrm{a}$ \\
$16.99 \mathrm{a}$ & $41.10 \mathrm{a}$ \\
$40.56 \mathrm{a}$ & \\
\hline *Mean values with the same lower-case letters are not significantly different at 95\% confidence level (p>0.05) according to Duncan's mean separation test.
\end{tabular}

According to Table 5 and statistical analysis, addition of $\mathrm{KBH}_{4}$ to white liquor has no significant effect on the physical and optical properties of the $R$. pseudoacacia pulps. However, in many studies it was reported that $\mathrm{NaBH}_{4}$ addition to cooking liquor increased the physical and optical properties of pulps. Gulsoy et al., (2016) determined that the physical properties of $\mathrm{KBH}_{4}$-added Pinus pinaster pulps were found to be lower than those of $\mathrm{KBH}_{4}$-free pulps. In a study conducted by Erkan et al., (2020) on the effects of using $\mathrm{KBH}_{4}$ in the pulp production from Pinus pinea wood, they found that $\mathrm{KBH}_{4}$ has no significant effect on physical properties. However, Cicekler and Tutus (2019) reported that using $\mathrm{KBH}_{4}$ in pulp production from Pinus brutia woods has positive effects on physical properties. According to these results, it can be understood that using $\mathrm{KBH}_{4}$ in pulp production does not have a clear effect on the physical properties of the pulp. Although the use of $\mathrm{KBH}_{4}$ slightly improves the optical properties of pulps, it is understood from Table 5 that there is no statistically significant effect. While $\mathrm{NaBH}_{4}$ has a bleaching effect on the pulp (Saracbasi et al., 2016), $\mathrm{KBH}_{4}$ did not affect the optical properties in this study.

\section{Conclusion}

It was determined that the yields and polymerization degrees of the $R$. pseudoacacia pulps produced by the $\mathrm{KBH}_{4}$ added soda method increased and the kappa numbers decreased. $\mathrm{KBH}_{4}$, which was added to the solution in the pulp production from wood with using soda method, prevents the peeling reaction that may occur by reducing the carbonyl groups at the reducing ends of the cellulose chain to hydroxyl groups during cooking. Although $\mathrm{KBH}_{4}$ prevented degradation of carbohydrates, it did not have a statistically significant effect on the physical properties of pulps. It was also observed that the addition of $\mathrm{KBH}_{4}$ to the cooking solution in pulp production from $R$. pseudoacacia wood had no significant effect on the optical properties of the pulps.

\section{References}

Akgul, M., Erdonmez, I., Cicekler, M., Tutus, A., 2018. The investigations on pulp and paper production with modified kraft pulping method from Canola (Brassica napus L.) stalks. Kastamonu University Journal of Forestry Faculty, 18(3): 357365

Akgul, M., Temiz, S., 2006. Determination of Kraft-NaBH 4 pulping conditions of Uludag fir (Abies bornmulleriana Mattf.). Pakistan Journal of Biological Science, 9(13): 2493-2497.

ASTM E313, 2020. Standard practice for calculating yellowness and whiteness indices from instrumentally measured color coordinates. American Society for Testing and Materials, PA, USA.

Birinci, E., Tutus, A., Cicekler, M., 2020. Evaluation of Rhododendron luteum and Rhododendron ponticum in pulp and paper production. Drvna industrija, 71(4): 365-370.
Brännvall, E., 2018. Increasing pulp yield in kraft cooking of softwoods by high initial effective alkali concentration (HIEAC) during impregnation leading to decreasing secondary peeling of cellulose. Holzforschung, 72(10): 819-827.

Cicekler, M., Tutus, A., 2019. Effects of potassium borohydride on the Pinus brutia pulp properties. Kahramanmaras Sutcu Imam University Journal of Engineering Sciences, 22(2): 38-47.

Copur, Y., Tozluoglu, A., 2008. A comparison of kraft, PS, kraft$\mathrm{AQ}$ and kraft-NaBH $\mathrm{N}_{4}$ pulps of Brutia pine. Bioresource Technology, 99(5): 909-913.

Correia, F.M., d'Angelo, J.V.H., Almeida, G.M., Mingoti, S.A., 2018. Predicting Kappa number in a Kraft pulp continuous digester: A comparison of forecasting methods. Brazilian Journal of Chemical Engineering, 35(3): 1081-1094.

Erkan, S., Cicekler, M., Tutus, A., 2020. Comparison of Pinus pinea heartwood and sapwood pulps obtained by sodapotassium borohydride method. Düzce University Journal of Science \& Technology, 8(3): 1894-1902.

Eroglu, H., 1981. Cooking wood chips with oxygen alkali method and bleaching pulp. Journal of Karadeniz Technical University Faculty of Forestry, 2: 314-315.

Gulsoy, S.K., Eroglu, H., 2011. Influence of sodium borohydride on kraft pulping of European black pine as a digester additive. Industrial \& Engineering Chemistry Research, 50(4): 24412444.

Gulsoy, S.K., Oguz, S., Uysal, S, Simsir, S., Tas, M., 2016. The influence of potassium borohydride $\left(\mathrm{KBH}_{4}\right)$ on kraft pulp properties of Maritime pine. Journal of Bartin Faculty of Forestry, 18(2): 103-106.

ISO 11476, 2010. Paper and board-Determination of CIE whiteness, $\mathrm{C} / 2$ degrees (indoor illumination conditions). International Organization for Standardization, Geneva, Switzerland.

ISO 2469, 2014. Paper, board and pulps-Measurement of diffuse radiance factor (diffuse reflectance factor). International Organization for Standardization, Geneva, Switzerland.

ISO 5267-1, 1999. Pulps-Determination of drainability-Part 1: Schopper-Riegler method. International Organization for Standardization, Geneva, Switzerland.

ISO 5269-2, 2014. Pulps-Preparation of laboratory sheets for physical testing-Part 2: Rapid-Köthen method. International Organization for Standardization, Geneva, Switzerland.

ISO 5351, 2010. Pulps-Determination of limiting viscosity number in cupri-ethylenediamine (CED) solution. International Organization for Standardization, Geneva, Switzerland.

Istek, A., Gonteki, E., 2009. Utilization of sodium borohydride $\left(\mathrm{NaBH}_{4}\right)$ in kraft pulping process. Journal of Environmental Biology, 30(6): 951-953.

Istek, A., Ozkan, I., 2008. Effect of sodium borohydride on Populus tremula L. kraft pulping. Turkish Journal of Agriculture and Forestry, 32: 131-136.

Kirci, H., 2006. Pulp Industry Lecture Notes, Karadeniz Technical University, Faculty of Forestry Publication, Trabzon, Turkey.

Meller, A., 1963. Retention of polysaccharides in kraft pulping. Part 1. The effect of borohydride treatment of Pinus radiata wood on its alkali stability. Tappi, 46(5): 317-319.

Misra, N.D., 1973. A tentative method of grading hardwoods for chemical grade pulp. Indian Pulp and Paper, 27(10): 7-10.

Pettersson, S.E., Rydholm, S.A., 1961. Hemicelluloses and paper properties of birch pulps, Part 3. Svensk Papperstidning, 64(1): 4-17. 
Saracbasi, A., Sahin, H.T., Karademir, A., 2016. Effects of sodium borohydride addition to kraft pulping process of some pine species. Journal of Forestry Research, 1(4): 134-143.

Smook, G.A., 1992. Handbook for Pulp and Paper Technologists. Angus Wilde Publication, Vancouver, Canada.

Tappi T236, 2013. Kappa number of pulp. TAPPI, Atlanta, USA.

Tappi T402, 2013. Standard conditioning and testing atmospheres for paper, board, pulp handsheets, and related products. TAPPI, Atlanta, USA.

Tappi T403, 2015. Bursting strength of paper. TAPPI, Atlanta, USA.

Tappi T494, 2006. Tensile properties of paper and paperboard (using constant rate of elongation apparatus) TAPPI, Atlanta, USA.

Tavast, D., Brännvall, E., 2017. Increased pulp yield by prolonged impregnation in softwood kraft pulping. Nordic Pulp \& Paper Research Journal, 32(1), 14-20.

Tutus, A., Alma, M.H., 2005. Use of boron compounds in pulp and bleaching. I. National Boron Workshop Proceedings, 28-29 April, Ankara, Turkey, pp. 399-403.

Tutus, A., Ates, S., Deniz, I., 2010. Pulp and paper production from spruce wood with kraft and modified kraft methods. African Journal of Biotechnology, 9(11): 1648- 1654.
Tutus, A., Cicekler, M., 2016. Evaluation of common wheat stubbles (Triticum aestivum L.) for pulp and paper production. Drvna Industrija, 67(3): 271-279.

Tutus, A., Cicekler, M., Ayaz, A., 2016. Evaluation of apricot (Prunus armeniaca L.) wood on pulp and paper production. Turkish Journal of Forestry, 17(1): 61-67.

Tutus, A., Cicekler, M., Deniz, I., 2012. Using of burnt red pine wood for pulp and paper production. Kahramanmaras Sutcu Imam University Journal of Engineering Sciences, Special Issue: 90-95.

Tutus, A., Cicekler, M., Karatas, B., 2011. Pulp and paper production by Kraft-Sodium Borohydride method from poppy Stems. II. International Non-Wood Forest Products Symposium, 8-10 September, Isparta, Turkey, pp. 183-190.

Tutus, A., Cicekler, M., Ozdemir, F., Yilmaz, U., 2014. Evaluation of Diospyros kaki pulp and paper production. II. National Mediterranean Forest and Environment Symposium, 22-24 October, Isparta, Turkey, pp. 775-784.

Tutus, A., Kazaskeroglu, Y., Cicekler, M., 2015. Evaluation of tea wastes in usage pulp and paper production. Bioresources, 10(3): 5407-5416. 